\title{
Board Characteristics and Firm Performance: Evidence from Nigerian Quoted Companies
}

\author{
Ilaboya, 0. J. (PhD, FCA, FCTI) \\ Associate Professor of Accounting \\ ojwhyte@yahoo.com, ofuanwhyte@gmail.com \\ Obaretin 0. (Msc, ACA, ACTI) \\ Department of Accounting, Faculty of Management Sciences, University of Benin, Benin City, Edo State, Nigeria \\ obasi4uy2k@yahoo.com
}

Doi:10.5901/ajis.2015.v4n1p283

Abstract

The broad objective of this study is to investigate the relationship between board characteristics and corporate performance. Time series data from 166 firms quoted on the Nigerian Stock Exchange market from 2005 to 2012 in the Food and Beverages sector was used for the study. We adopt the log of profit after tax as the measure of performance. The study found a positive and significant relationship between independent directors on audit committee and firm performance in Nigeria. The study suggests the need for a competent and sizeable board and a cut down on the waste of resources on too frequent board meetings as the findings reveals that there is a negative relationship between board diligence and performance. The study also gave emphasis on the need to strengthen the independence of audit committee to continuously achieve the control mechanism and oversight functions.

Keywords: independent directors, board meetings, firm performance, audit committee, corporate governance, board composition

\section{Introduction}

Issues of governance and corporate performance have received serious empirical consideration in recent times. This unending enthusiasm on governance research may have been sustained by the high profile corporate demise, financial scandals and the global financial meltdown resulting in general loss of public confidence and investors apathy. Corporate governance transcends the daily management of business activities (Bairathi, 2009). Corporate governance is dynamic and appears broader than the conventional management practices. It is concerned with transparency in business dealings, probity and accountability, ethical conduct, fairness and strict compliance with both regulatory and ethical standards. Against the backdrop of the robustness of governance issues, one fundamental question becomes pertinent: do board characteristics affect the performance of the organisation?

This study explores the relationship between board characteristics and corporate governance performance against the backdrop of the trade-off between investors' risk minimisation and returns maximisation. It is expected that organisations with strong governance practices should enjoy a market premium. But there has been conflicting empiric on board characteristics and firm performance. This lack of convergence is the driving force behind this current study.

Our study is about the first large-scale long time horizon study of this topical issue having focus on 166 firms of the Food and Beverages sector of the Nigeria Stock Exchange, from 2005 to 2012 which is approximately 8 years. We use the log of accounting construct of profit after tax to capture performance instead of the usual barrage of performance variables in line with the views of Van Ness, Miesing and Kang (2010). All independent variables were selected based on extant empirical literature.

Contrary to expectation, we find a positive and statistically significant relationship between board size and firm performance. This result debunked the Berle and Means (1932) board failure hypothesis which states that boards lack the incentive and capability to objectively represent the interest of shareholders. The results run contrary to the conventional wisdom that larger boards decrease firm performance.

The study advances an extensive developing country perspective, since the global financial crisis requires a multidimensional approach. It is one of the very few post financial crisis study of governance and performance dynamics that integrates both large scale firms and extensive period.

We proceed as follows: Section II focus on review of extant literature on board characteristics and corporate 
performance nexus. Section III presents the data source and methodology with emphasis on the analytical framework and model. The estimation results and discussion of findings is in section IV while section V presents the concluding remarks.

\section{Review of Prior Studies}

\subsection{Board Size and Firm Performance}

The boards of directors ensure that organisations operate within the law and uphold the fiscal integrity of such operation. The relationship between board size and firm performance has received serious empirical consideration with the earliest being Lipton and Lorch (1992). Their study recommended a board size of 7 or 8 and concluded that larger board size may result in time consuming effort in decision making. Boards monitor management to reduce the level of agency costs and also chart the strategic course for the organsation, to eliminate dinosaur dynamics - too big to change. Bathula (2008) focusing on a sample of 158 Countries from 2004 to 2007 for New Zealand quoted companies, found a positive relationship between board size and firm performance. Larger boards can distribute the workload through the use of committees to ensure in depth analysis of issues and avoid burn out. VanNess, Miesing and Kang (2010) focused on American listed firms from 2006 to 2007 and discovered that larger boards increase revenue. What this portends for the organsation is that the diverse expertise and experience of the board members impacted positively on the revenue growth of the organisation. In the same vein, Daily and Dalton (1993) and Johl, Kaur and Cooper (2013), found a significant positive relationship between board size and firm performance.

\subsection{Audit Committee Independence and Firm Performance}

Audit committee forms part of the internal control mechanism of the firm and helps to strengthen corporate governance. Klein (2002) is of the opinion that audit committee independence decrease with increase growth tendency of the organisation. They believe that the independence of the audit committee may reduce the growth potentials of the organisation as the internal auditors and management focus more on meeting the requirements of the committee thereby shifting attention from the core business of the organisation. Krishnan (2005) posits that independent audit committee and committee with the requisite expertise will help to reduce internal control issues in the organisation. Even though, the reduction may not necessarily translate into increased growth (Hsu, 2008). Mak and Kusnadi (2005) focusing on Singaporean and Malaysian companies, found no significant relationship between firm value and audit committee independence. In the same vein, Hutchinson and Zain (2009) studied 60 Malaysian companies and found no positive relationship between audit committee independence and corporate performance. Their result signifies a conflict effect between audit committee and internal audit quality.

\subsection{Board Diligence and Firm Performance}

Board diligence here refers to the number or frequency of board meetings. While some studies advise against frequent board meetings, others believe that frequent meetings will enhance the performance of management. Gosh (2007) found a statistically significant impact of board diligence on firm performance, noting that $10 \%$ increase in diligence increases the performance of the organisation by 1\%. Johl, Kaur and Cooper (2013) used financial and non financial data from companies listed on the Malaysian Stock Exchange market in 2009. The result of the study reported a negative relationship between board diligence and financial performance. The implication of the finding is that less frequent, but meaningful meetings should be encouraged. Frequent meetings will result in diverting organizational resources to less productive activities (Chorsch \& Maclver, 1989). This negative relationship is also consistent with Johl (2013) and Lipton and Lorsch (1992). However, others believe that infrequent board meetings will result to insignificant influence on the activities of management (Mace, 1996 and Useem, 2006).

\subsection{Board Independence and Firm Performance}

A board is said to be independent, when the number of independent ,non-executive directors not associated with top executives of the firm are more. MillStein (1993) is of the view that directors who are independent of management can perform their oversight functions better. Yemack (1996) reported a significant negative correlation between independent 
directors and performance measured by Tobin's Q. in the same vein, Agrawal and Knoeber (1996) reported a negative correlation between independent directors and Tobin's Q. Klein (1998) also reported negative correlation between performance expressed as a change in market value of equity and independent directors. Bhagat and Black (2002) using a sample of 934 American firms between 1985 to 1995 found no positive relationship between board independence and firm performance in United States of American.

Event studies of appointment of outside directors are also found to exert positive influence on corporate performance (Rosenstein \& Wyatt, 1990). Even though according to Bhagat and Black (2002), the improved performance from event studies may be attributable to signaling effect. Johl et al (2013) found a negative relationship between board independence and firm performance. This means higher ratio of non-executive directors does not necessarily affect the performance of the organisation.

\subsection{Board Expertise and Firm Performance}

The functional experience and professional background of board members has now been recognized as very significant germane to the performance of the organisation. The fundamental question therefore is: does the inclusion of finance professionals on the board increase the performance of the orgnisation? Agrawal and Chadha (2005) found board expertise to be associated with a lower incidence of restated earnings. VanNess, et al (2010) investigated board of directors composition and corporate performance and found a negative relationship between board expertise and firm performance. This means the intricacies of daily business activities, transcends professional expertise and earnings growth requires greater entrepreneurial skills which finance knowledge, may not necessarily confer. Gentenbein and Volante (2012) focused on 1574 directors firm 224 Switzerland quoted companies and reported a negative relationship between board expertise and firm performance.

\section{Methodology}

\subsection{Theoretical Framework and Model Specification}

The framework for the analysis of board characteristics and corporate performance is the stakeholder's theory. The choice of the theory is premised on the limitation of the shareholders theory which we consider too narrow to address the board characteristics dynamics. According to Freeman and Reed (1983), stakeholders may be viewed from two perspectives as: groups who ensure the existence and success of the organsation and groups, individuals capable of affecting and being affected by the organisation. Stakeholders include employees, financial customers and communities. In accordance with the stakeholders enabling rules, directors have a duty of care to exercise reasonable judgment in piloting the affairs of the organisation. Extant literature has identified a set of explanatory variables collectively referred to as board functionalities. These board activities are thought to affect the performance of the organisation.

Assume a linear relationship between profitability and the board variables of: size, independence, expertise, diligence and audit committee independence.

Board size is believed to have a negative relationship with corporate performance (Bhagat \& Black, 202; Yemack , 1996) even though some established positive relationship between board size and firm performance. Therefore,

$P A T=f(B D S I Z E)$

Independent directors on the board have reported a mixed empirical reaction with some declaring negative relationship (Yemack, 1996; Klein, 1998). And others reported positive impact (VanNess et al, 2010; Bathwal, 2008). Hence,

$P A T=f(B D I N D)$

The expertise of the board of directors has also been studied as explanatory variable in board researches (Gantenbein \& Vocante, 2012): Hence,

$P A T=f(B D E X P)$

Board diligence, a proxy for number of board meetings has also received attention on studies of board functionalities and corporate performance (Gosh, 2007). Therefore,

$P A T=f(B D D I L I)$

The independence of the audit committee has also received serious empirical consideration in modern times (Mak \& Kusnadi, 2005). Hence,

$P A T=f($ AUDIND $)$ 
Combining the five equations in a functional form,

$P A T=f(B D S I Z E, B D I N D, B D E X P, B D D I L L, A U D I N D)$

In econometric form:

$$
\operatorname{LogPAT}_{i t}=\alpha_{0}+\alpha_{1} B D S I Z E_{i t}+\alpha_{2} B D I N D_{i t}+\alpha_{3} B D E X P_{i t}+\alpha_{4} B D D I L I_{i t}+\alpha_{5} A U D I N D X 5_{i t}+\mu_{t} \text { (vii) }
$$

Where:

PAT = natural log of the value of profit after tax (the dependent variable)

BDSIZE = board size

BDIND = board independence

BDEXP = board expertise

BDDILI = board diligence, which is the number of board meetings attended by the board of directors

AUDIND $=$ the independence of the external auditors

$U=$ error term

$\alpha_{1}, \ldots, \alpha_{5}=$ unknown coefficient of the variables. It is presumptively expected that $\alpha_{1}<0$ that is the size of the board of director will negatively affect profitability. $\alpha_{1}<0$. More independent directors cannot be influenced by management and hence should increase profit. $\alpha_{3}, \alpha_{4}, \alpha_{5}>0$.

The variables in our model are operationalised in Table 1 below.

Table 1: Variables, Definitions and Notations

\begin{tabular}{|l|c|l|c|}
\hline Variable & Notation & Definition & Expected sign \\
\hline Profit after tax & PAT & This is taken as natural log of profit after tax & \\
\hline Board size & BDSIZE & This is the total number of directors on the board & negative \\
\hline Board independence & BDIND & This is the number of independent directors on the board & Positive \\
\hline Board expertise & BDEXP & Education, skills and professional status of directors & Positive \\
\hline Board diligence & BDDILI & A measure of the number of board meetings & Positive \\
\hline Audit committee independence & AUDIND & Number of independent directors on the audit committee & positive \\
\hline
\end{tabular}

Source: Researchers' Compilation 2014

\subsection{Data Source and Estimation Technique}

Data for this study is a combination of longitudinal and time series data from 166 firms quoted on the Nigerian Stock Exchange market from 2005 to 2012. The study is a content analysis of the financial statements of all companies in the Food and Beverages sector of the Nigerian bourse. Contrary to most extant studies, we adopted the log of profit after tax as the measure of performance.

\section{Estimation Result and Discussion}

\subsection{Descriptive Statistics and Diagnostics}

Table 11: Pooled Descriptive Analysis

\begin{tabular}{|c|c|c|c|c|c|c|}
\hline & PAT & BDSIZE & BDIND & BDEXP & BDDILI & AUDIND \\
\hline Mean & 4705.89 & 9.114458 & 0.582097 & 2.746988 & 4.415663 & 1.065764 \\
\hline Maximum & 173511 & 18 & 3.6667 & 4 & 18 & 3 \\
\hline Minimum & -11254 & 3 & 0.1111 & 1 & 2 & 0.6667 \\
\hline Jarque-Bera & 64538.18 & 9.24327 & 671.9122 & 55.14691 & 7872.043 & 1825.014 \\
\hline Probability & 0 & 0.009837 & 0 & 0 & 0 & 0 \\
\hline Observations & 166 & 166 & 166 & 166 & 166 & 166 \\
\hline
\end{tabular}

Source: Researchers' Compilation, 2014

From the result, the average profit after tax is N4705.89 billion and varies between N173.5113 and N11.2543. The 
average board size in our sample is 9.11. This is consistent with Jensen (1993) and francis, Hasan and Wu (2012). The minimum board size is 3 with a maximum of 18 directors. We find $58.2 \%$ level of board independence which is consistent to Francis et al (2012) who found 60\% board independence. The large Jarque-Bera statistics are indicative of normality of the regression variables couple with the $(0.000)$ probability values.

Table 111: Results of the Variance Inflation Factor Test

\begin{tabular}{cccc}
\hline \hline Variable & $\begin{array}{c}\text { Coefficient } \\
\text { Variance }\end{array}$ & $\begin{array}{c}\text { Uncentered } \\
\text { VIF }\end{array}$ & $\begin{array}{c}\text { Centered } \\
\text { VIF }\end{array}$ \\
\hline \hline C & 60525403 & 57.56072 & NA \\
BDSIZE & 183444.5 & 15.60567 & 1.112780 \\
BDIND & 3038011. & 2.006997 & 1.028029 \\
BDEXP & 4000348. & 29.93101 & 1.223218 \\
BDDILI & 438702.7 & 9.176194 & 1.041324 \\
AUDIND & 13524845 & 15.68464 & 1.074874 \\
\hline \hline
\end{tabular}

Source: Researchers' Compilation, 2014.

The results of the variance inflation factor shows that all the variables in the regression model are relevant to the study, with VIF factors all below the benchmark of 10 , which is indicative of the absence of multicollinearity. The DW statistics of 1.95 (fixed effect model) and (1.77) (random effect model) are both substantially close to the (2.00) mark which signifies the absence of autocorrelation.

Table 1V: Results of the White Heteroskedasticity Test and Breusch-Godfrey Serial LM Test

Heteroskedasticity Test: Breusch-Pagan-Godfrey

\begin{tabular}{cccc}
\hline \hline F-statistic & 1.932174 & Prob. F(4,161) & 0.1076 \\
Obs*R-squared & 7.603706 & Prob. Chi-Square(4) & 0.1072 \\
Scaled explained SS & 149.0450 & Prob. Chi-Square(4) & 0.0000 \\
& & & \\
\hline \hline
\end{tabular}

Breusch-Godfrey Serial Correlation LM Test:

\begin{tabular}{cccc}
\hline \hline F-statistic & 1.269150 & Prob. F(2,158) & 0.2839 \\
Obs*R-squared & 2.624656 & Prob. Chi-Square(2) & 0.2692 \\
& & & \\
\hline \hline
\end{tabular}

Source: Researchers' Compilation, 2014.

According to White (1980), the presence of heteroskedasticity can lead to inefficient parameter estimates and faulty inferences. To circumvent the problems of inefficient parameter estimates and faulty inferences, we tested for heteroskedasticity using the white test and the results revealed the absence of heteroskedasticity. F-statistic and obs $^{*}$ Rsquared with p-values of (1.93) and (1.60) respectively. The probabilities of $(0.10)$ and $(0.10)$ exceeds the $5 \%$ level of significance. The Breusch-Godfrey Serial correlation LM test with probability values of $(0.28)$ and $(0.26)$ respectively indicates the absence of autocorrelation in the regression model since the f-statistic and obs*Rsquared are greater than the critical values at $5 \%$ level of significance. 
Table V: The Results of the Hausman' Test

\begin{tabular}{cccc}
\hline \hline Test Summary & Chi-Sq. Statistic & Chi-Sq. d.f. & Prob. \\
\hline \hline Period random & 2.136065 & 5 & 0.8300 \\
\hline \hline
\end{tabular}

Source: Researchers' Compilation, 2014

The result of the Hausman's test is presented in Table 5. The Hausman's test helps to determine whether the fixed or random effect approach of panel data analysis is appropriate. The result from the test shows chi-square value of (2.13) with a probability value of $(0.83)$ which exceeds the $p$-value of $(0.05)$, which confirms the supremacy of the fixed effect model

Table V1: Results from the Pooled OLS, FEM and REM

\begin{tabular}{|c|c|c|c|}
\hline \multicolumn{2}{|c|}{ POOLED OLS } & RANDOM EFFECT MODEL & FIXED EFFECT MODEL \\
\hline Dependent Variable: PAT & & & -39683.49 \\
\hline C & -22528 & -21765.49 & $(-3.84)^{\star * *}$ \\
\hline & $(-2.86)^{\star * *}$ & $(-2.73)^{\star * *}$ & 3818.54 \\
\hline BDSIZE & 2740.62 & 2663.24 & $(5.95)^{\star * *}$ \\
\hline & $(6.32)^{\star *}$ & $(6.08)^{\star * *}$ & 1113.91 \\
\hline BDIND & 1820.46 & 2037.34 & $(0.46)$ \\
\hline & $(1.03)$ & $(1.14)$ & -1967.68 \\
\hline BDEXP & -3857.40 & -3507.02 & $-19.71)$ \\
\hline & $(-1.90)^{* *}$ & $(-1.71)^{*}$ & $(-0.22)$ \\
\hline BDDILI & 321.42 & 159.66 & 14254.89 \\
\hline & $(0.47)$ & $(0.23)$ & $(3.49)^{* * *}$ \\
\hline AUDIND & 9731.89 & 9326.74 & 0.42 \\
\hline R-squared & $(2.61)^{\star * *}$ & $(2.45)^{\star * *}$ & 0.31 \\
\hline Adjusted-R-Squared & 0.24 & 0.26 & 3.65 \\
\hline F-Statistics & 0.22 & 0.20 & 1.95 \\
\hline DW-Statistics & 10.63 & 4.29 & \\
\hline & 1.77 & 1.78 & \\
\hline
\end{tabular}

Source: Researchers' Compilation 2014

The coefficient of multiple determination shows the explanatory power of the independent variables to be (0.42). This means that over $42 \%$ of the variation in profit in Nigeria is accounted for by the explanatory variables. The f-statistics of the fixed effect model of (3.65) shows the statistical significance of the model at the $5 \%$ level.

Contrary to expectation, we found a positive and statistically significant relationship between board size and performance with a t-value of (5.95) at the $1 \%$ level. This means that larger board size increases the performance of quoted firms in Nigeria. The descriptive statistics reported a mean board size of 9 members. Large board size allows for effective operating committee and adhoc committee even though too many committees can also be counted productive through burnout. Our positive significant relationship is consistent with the change, prospect, perspective of Shleifer and Vishny (1997); Bathula (2008); VanNess et al (2010) and Johl et al (2013). Even though other studies (Lipton \& Lorsch, 1992 and Bhagat \& Black, 2002), found negative relationship between board size and firm performance.

The parameter of board independence was found to be positive but statistically insignificant having reported a tvalue of (0.46). The result is not surprising since the mean independence value is seen to be $58 \%$ which is slightly above average. What this means is that independent directors on the board does not affect the performance of the organisation. Our finding is consistent with the insignificant relationship reported by Yemack (1996); Agrawal and Knoeber (1996); Klein (1998) even though their studies reported negative relationship between board independence and firm performance.

Board expertise is negative and statistically insignificant with a t-value of $(-0.71)$. This means the financial expertise 
of board members does not necessarily translate into improved performance. The result is however not surprising. This is because in addition to the fact that the sample under study is not drawn from the financial sector, corporate management transcends financial expertise. According to Desendor (2009), as may be applicable to manufacturing companies which is our centre of focus, knowledge of the industry, competitors, and regulations may be more important. The result corroborates VanNess et al (2010) who opined that revenue growth goes beyond financial expertise to serious entrepreneurial efforts and Gantenbein and Volonte (2012) who focused on companies with different divisions and departments.

Board diligence coefficient is negative and statistically insignificant with a t-value of $(-0.22)$ which means increase board meetings reduces the performance of the organisation. Increase in board meetings according to Johl et al (2013) amounts to channeling hard earned resources from productive to unproductive activities. Board meetings should be less frequent to avoid unnecessary wasting of quality time and effort. This position is consistent with Lipton and Lorsch (1992) and Gosh (2007).

Audit committee independence is positive and statistically significant with a robust t-value of (3.49) signifying that independent audit committee will improve the oversight function of the committee which will no doubt translate into improved corporate performance. Audit committee forms part of the entire organisational control mechanism which helps to fortify corporate governance practices though there are evidences that there is possibility of conflict effect between audit committee effectiveness and internal audit quality (Mak \& Kusnadi, 2005; Hutchinson \& Zain, 2009). It is therefore imperative to strike a balance so as to avoid distractions occasioned by conflict of interest. According to Krishnan (2005), independent audit committee will help to reduce possibility for internal control crisis in organisations.

\section{Concluding Remarks}

The paper examined board characteristics and corporate financial performance dynamics using a combination of cointegration and error correction mechanism. The estimated results suggested positive relationship between board size and corporate financial performance. The study reports a mean board size of 9 which is consistent with Jensen (1993) and Francis et al (2012). Also, we find a positive and significant relationship between independent directors on audit committee and firm performance in Nigeria. Board diligence and board expertise are both negative and insignificant.

The study no doubt presents a developing economy perspective on the relationship between board structure and corporate performance against the backdrop of the conflicting reports in extant literature. Our study contributes to the existing body of knowledge: our finding of positive relationship between board size and firm performance debunked the Berle and Means (1932) board failure hypothesis which states that boards lack the incentive and the capacity to objectively champion the course of shareholders.

While this study does not foreclose future researches in the topical issue, our analysis presents interesting policy considerations. First, the positive impact of board size on corporate performance suggests the need for a competent and sizeable board. Secondly, the is need to cut down on the waste of resources on too frequent board meetings as the study reports a negative relationship between board diligence and performance. Third, the positive relationship between independent directors on audit committee suggests the need to strengthen the independence of audit committee to continuously achieve the control mechanism and oversight functions. The analysis did not however address the financial sector of the Nigerian economy which appears more turbulent. Extending the study to the Nigerian banking sector remains part of future study.

\section{References}

Agrawal, A., \& Chadha, S. 2005. Corporate governance and accounting scandals. Journal of Law and Economics, 68, 371-406.

Agrawal A, \& Knoeber C. R. (1996). Firm performance and mechanisms to control agency problems between managers and shareholders. Journal of Finance Quant. Anal., 31, 377-397.

Bairathi, V. (2009). Corporate governance: A suggestive code. International Resource Journal , 11 (6), 733-757.

Bhagat, S. \& Black, B. (2002). The non-correlation between board independence and long-term firm performance. Journal of Corporate Law, 27, 231-274.

Bathula , H. (2008). Board Characteristics and Firm Performance: Evidence from New Zealand. Unpublished thesis submitted to Auckland University of Technology.

Berle, A., \& Means, G. (1932). The modern corporation and private property, New York: Macmillan Publishing Co.

Daily C. M, \& Dalton D. R (1993). Boards of directors, leadership and structure: control and performance implications. Entrepreneurship Theory Pract., 17: 65-81.

Gantenbein, P. \& Volonté, C. (2012). Director Characteristics and Firm Performance 
Ghosh, S. (2007). Board diligence, director busyness and corporate governance: An empirical analysis for India. Review of Applied Economics, 3 (1-2), 91-104.

Hutchinson, M, N., \& Zain, M. M. (2009) Internal audit quality, audit committee independence, growth opportunities and firm performance. Corporate Ownership and Control, 7(2). 50-63.

Hsu, H-E. (2008). Audit Committees in U.S. Entrepreneurial Firms. Journal of American Academy of Business. 13(1): 121-128.

Jensen, M. (1993). The modern industrial revolution, exit, and the failure of internal control mechanisms. Journal of Finance, 48 (3): 831 880.

Johl, S. K., Kaur, S. \& Cooper, B. J. (2013). Board characteristics and firm performance: evidence from Malaysian public listed firms. Journal of Economics, Business and Management, 3, (2)

Klein, A. (2002), Economic determinants of audit committee independence. The Accounting Review, 77 (2): $435-452$.

Lipton, M. \& Lorsch, J. (1992). A modest proposal for improved corporate governance. Business Lawyer, 48, 59-77.

Mace, M. (1986). Directors: Myth and reality. Boston: Harvard Business School Press.

Mak, Y.T. \& Kusnadi, Y. (2005). Size really matters: Further evidence on the negative relationship between board size and firm value. Pacific-Basin Finance Journal, 13(3): 301-318.

Millstein, I. (1993). The evolution of the certifying board. Business Lawyer 48, 1485-1497.

Rosenstein, S., \& J. Wyatt. (1990). Outside directors: Board independence and shareholder wealth. Journal of Financial Economics, 26 (August): 175-191.

Shleifer A, \& Vishny R. W (1997). A survey of corporate governance. Journal of Finance, 52 (2): 737-783.

Useem, M. (2006). How well-run boards make decisions. Harvard Business Review (November): 130-138.

Van Ness, R. K., Miesing, P. \& Kang, J. (2010). Board of director composition and financial performance in a Sarbanes-Oxley. Academy of Business and Economics Journal 10 (5), 56-74

White, H., (1980). A Heteroskedasticity-Consistent Covariance Matrix Estimator and a Direct Test for Heteroskedasticity. Econometrica: Journal of the Econometric Society, 48 (4), 817-838.

Yermack, D. (1996). Higher market valuation of companies with a small board of directors. Journal of Financial Economics, 40, (2) 85211. 